\title{
Contribution of endothelin receptors and cyclooxygenase-derivatives to the altered response of the rabbit renal artery to endothelin- 1 in diabetes
}

\author{
Vannina G. Marrachelli a, Francisco J. Miranda ${ }^{a}, *$, José A. Alabadí ${ }^{a}$, \\ Silvia Lloréns ${ }^{\mathrm{c}}$, Enrique Alborch ${ }^{\mathrm{a}, \mathrm{b}}$ \\ a Departamento de Fisiología, Facultad de Farmacia, Universidad de Valencia, Avda. Vicente Andrés Estellés s/n, 46100 Burjassot, Valencia, Spain \\ ${ }^{\mathrm{b}}$ Research Centre, Hospital La Fe, Valencia, Spain \\ ${ }^{\mathrm{c}}$ Departamento de Ciencias Médicas, Facultad de Medicina, Universidad de Castilla-La Mancha, Albacete, Spain
}

Received 4 August 2005; received in revised form 16 January 2006; accepted 20 January 2006

Available online 28 February 2006

\begin{abstract}
The influence of diabetes on regulatory mechanisms and specific receptors implicated in the response of isolated rabbit renal artery to endothelin-1 was examined. Endothelin-1 induced a concentration-dependent contraction that was less potent in arteries from diabetic rabbits than in arteries from control rabbits. Endothelium removal or $N^{\mathrm{G}}$-nitro-L-arginine (L-NOARG) enhanced contractions to endothelin-1 either in control and diabetic arteries. Indomethacin inhibited endothelin-1-induced response in control arteries, but enhanced it in diabetic arteries. In contrast to that observed in rubbed and in L-NOARG treated arteries, in the presence of indomethacin the contractile action of endothelin-1 was higher in diabetic arteries than in control arteries. Nimesulide enhanced endothelin-1 contractions both in control and diabetic arteries. Cyclo-(D-Asp-Pro-DVal-Leu-D-Trp) (BQ-123, endothelin $\mathrm{ET}_{\mathrm{A}}$ receptor antagonist), attenuated endothelin-1 vasoconstriction in control rabbits, while vasoconstriction resulted increased in diabetic rabbits. 2,6-Dimethylpiperidinecarbonyl- $\gamma$-Methyl-Leu- $N_{\text {in }}$-(Methoxycarbonyl)-D-Trp-D-Nle (BQ-788, endothelin $\mathrm{ET}_{\mathrm{B}}$ receptor antagonist), enhanced the contractile response in control rabbit arteries without modifying this response in diabetic rabbits. In summary, diabetes decreases the sensitivity of the rabbit renal artery to endothelin-1 by decreasing the ratio between vasoconstrictor and vasodilator prostanoids released after activation of endothelin $\mathrm{ET}_{\mathrm{A}}$ receptors.
\end{abstract}

(C) 2006 Elsevier B.V. All rights reserved.

Keywords: Diabetes; Arachidonic acid derivatives; Cyclooxygenase; Endothelin-1; Endothelin $\mathrm{ET}_{\mathrm{A}}$ and $\mathrm{ET}_{\mathrm{B}}$ receptors; Endothelium; $\mathrm{NO}$ (nitric oxide); Renal artery

\section{Introduction}

The WHO Multinational Study of Vascular Disease in Diabetes reported that cardiovascular disease is the most common cause of death accounting for $44 \%$ of deaths in Type I diabetes mellitus, followed by renal disease accounting for $21 \%$ of deaths (Morrish et al., 2001).

Vascular reactivity is regulated by a complex interaction between vasoconstrictor and vasodilator substances released from endothelium, smooth muscle cells, perivascular nerve endings and blood cells. The endothelium has a decisive role in regulating both the tone and the growth of the vessel wall by maintaining a critical balance between different constrictor

\footnotetext{
* Corresponding author. Tel.: +34 963544903; fax: +34 963543395.

E-mail address: francisco.j.miranda@uv.es (F.J. Miranda).
}

(endothelin-1, angiotensin II, thromboxane $\mathrm{A}_{2}$, prostaglandin $\mathrm{H}_{2}$ ) and relaxant (nitric oxide, prostacyclin, endotheliumderived hyperpolarizing factor) substances. Accordingly, the vasoconstrictor and mitogenic actions of endothelin-1 are opposed to those of vasodilator and antigrowth factors such as nitric oxide (NO) and prostacyclin secreted by endothelial cells. Smooth muscle cells are able to release vasoconstrictor and vasodilator prostaglandins. ATP, noradrenaline and neuropeptide $\mathrm{Y}$ are co-stored and released from vascular neuroeffector junctions (Huidobro-Toro and Donoso, 2005) and nitrergic perivascular nerve endings have been histochemically and functionally identified in the vessel wall (Haberberger et al., 1997; Jurzik et al., 2005).

Prostanoids derived from endogenous cyclooxygenases (COX)-mediated arachidonic acid metabolism play important roles in the maintenance of renal blood flow and salt and water 
homeostasis (Campean et al., 2003). In vascular biology, the two major products of $\mathrm{COX}$ are thromboxane $\mathrm{A}_{2}$, which is mainly formed by the constitutive isoform of COX, COX-1, and prostacyclin which is mainly produced in vascular cells by COX-1 and the inducible isoform COX-2. COX-1 is expressed constitutively in vascular endothelial cells and in smooth muscle cells whereas COX-2 may be induced in these tissues in response to vascular injury (Habib et al., 1993; Rimarachin et al., 1994).

Diabetes alters the responsiveness of different vascular beds to several vasoconstrictors and vasodilators, and it has been hypothesised that endothelial dysfunction could partially explain many of these altered responses (Haller, 1997; De Vriese et al., 2000). Since the discovery of endothelin-1 as the most potent vasoconstrictor and pressor substance (Yanagisawa et al., 1998), several events have suggested its implication in various cardiovascular disorders, including those related to diabetes mellitus. It is clear that many of the well-known metabolic abnormalities encountered in diabetes mellitus, such as those affecting plasma insulin, glucose and lipid levels, contribute individually and synergistically to alterations in the release and action of endothelin-1 (Hopfner and Gopalakrishnan, 1999). Endothelin-1 exerts a powerful vascular influence on the renal circulation, resulting in decreases in renal blood flow and glomerular filtration (Oyekan and McGiff, 1998). Urinary excretion of endothelin-1 is decreased in patients with recent-onset diabetes mellitus, thus suggesting a possible role of endothelin-1 in the pathogenesis of early diabetic nephropathy (Lam et al., 1995). Excessive endothelin-1 action in the diabetic glomerulus can cause enhanced matrix accumulation, proteinuria, and reduced glomerular filtration rate, existing abundant evidence in vivo that endothelin-1 antagonists ameliorate glomerular injury in animal models of diabetic nephropathy (Sorokin and Kohan, 2003).

We have previously reported that diabetes changes endothelial modulatory mechanisms in the rabbit renal artery (Alabadi et al., 2001; Miranda et al., 2002). In two recent studies we have reported that diabetes induces hyperreactivity of the rabbit basilar (Alabadí et al., 2004) and carotid (Lloréns et al., 2004) arteries to endothelin-1, via a mechanism that involves changes in the modulatory role of endothelial release of $\mathrm{NO}$ and prostanoids and in the role of endothelin $\mathrm{ET}_{\mathrm{A}}$ and $\mathrm{ET}_{\mathrm{B}}$ receptors. The aim of the present study was to analyse diabetes-induced changes in the reactivity of the rabbit renal artery to endothelin-1, including the study of the contribution of specific receptors and COX-1 and COX-2 derivatives on this response.

\section{Materials and methods}

Forty-eight male New Zealand white rabbits were used in the present study. Animals were randomly divided into two experimental groups: twenty five in the control group and twenty three destined for induction of experimental diabetes. Housing conditions and experimental procedures were in accordance with the European Union regulations on the use of animals for scientific purposes (86/609/EEC, Article 5,
Appendix II) and as promulgated by Spanish legislation on March 14, 1988 (RD 223/1988).

\subsection{Induction of diabetes and control animals}

For induction of experimental diabetes, rabbits weighing 2.0-3.2 kg were sedated with intramuscular injection of ketamine (40 mg; Ketolar $\left.{ }^{\circledR}\right)$. Diabetes was induced by injecting alloxan $\left(100 \mathrm{mg} \mathrm{kg}^{-1}\right)$ into the lateral ear vein. To prevent hypoglycaemia, $10 \mathrm{ml}$ of glucose $5 \%$ was injected intravenously after the alloxan, and drinking water was supplemented with $10 \%$ glucose for the first $24 \mathrm{~h}$ after the alloxan injection. Thereafter, the animals were maintained on tap water and regular food ad libitum for six weeks. A second group of rabbits $(2.1-3.0 \mathrm{~kg})$ was maintained under the same conditions for the same time period to serve as age-matched controls (henceforth "control rabbits"). Diabetic rabbits did not receive insulin through the six weeks and showed a marked increase in serum glucose and a failure to increase their body weight when compared with control rabbits. Table 1 shows the mean values of body weight and glycaemia before and six weeks after diabetes induction for the rabbits in the diabetic group and for the rabbits in the control group.

\subsection{Isometric tension recording}

Six weeks after diabetes induction, the diabetic and the agematched control rabbits were anaesthetised with sodium thiopental (sodium pentothal, 2\%, i.v.) and killed by injection of potassium chloride $(10 \mathrm{mEq}, 0.5 \mathrm{ml} / \mathrm{kg}$, i.v. $)$. The renal arteries were dissected free and cut into cylindrical segments measuring $4 \mathrm{~mm}$ in length. Each segment was prepared for isometric tension recording in an organ bath. Two stainless steel L-shaped pins (diameter, $207 \mu \mathrm{m}$ ) were introduced through the arterial lumen. One pin was fixed to the organ bath wall and the other pin was connected to a strain gauge for isometric tension recording (isometric tension transducer models Panlab UF-1 and Letica TRI 201). The organ bath contained $5 \mathrm{ml}$ of RingerLocke solution that was continuously bubbled with $95 \% \mathrm{O}_{2}$ and $5 \% \mathrm{CO}_{2}$ to provide a $\mathrm{pH}$ of 7.3-7.4. Temperature was kept at $37{ }^{\circ} \mathrm{C}$. A resting tension of $2 \mathrm{~g}$ was applied to the arterial segments, and they were allowed to equilibrate for a period of 60-90 min before the experiments were started. Tension was readjusted when necessary and the bath fluid was changed every

Table 1

Body weight and glycaemia in control and diabetic rabbits

\begin{tabular}{lccc}
\hline & Body weight $(\mathrm{kg})$ & Glycaemia $(\mathrm{mmol} / \mathrm{l})$ & $n$ \\
\hline $\begin{array}{l}\text { Control rabbits } \\
\text { Initial time }\end{array}$ & $2.50 \pm 0.08$ & $5.9 \pm 0.2$ & 25 \\
6 weeks after & $3.50 \pm 0.07$ & $5.8 \pm 0.2$ & 25 \\
& & & \\
Diabetic rabbits & & $5.9 \pm 0.2$ & 23 \\
Initial time & $2.52 \pm 0.08$ & $20.3 \pm 0.6^{\mathrm{a}}$ & 23 \\
6 weeks after & $3.08 \pm 0.08^{\mathrm{a}}$ & &
\end{tabular}

Results are means \pm S.E.M.

a Significantly different from corresponding value in control rabbits, $P<0.01$. 
$15 \mathrm{~min}$. After this period of equilibration, the reactivity of the arterial segments was checked by depolarisation with $50 \mathrm{mM}$ $\mathrm{KCl}$. There were not significant differences in the response to $\mathrm{KCl}$ between arteries from control and diabetic rabbits.

\subsection{Concentration-response curves of endothelin-1}

The experiments were carried out with renal arteries from both control and diabetic rabbits. Concentration-response curves for endothelin- $1\left(10^{-12}-3 \times 10^{-8} \mathrm{M}\right)$ were obtained by its cumulative addition to the organ bath. To assess the influence of the endothelium on the effect of endothelin-1, concentration-response curves were obtained with arteries from which the endothelium had been removed by rubbing the intimal surface with a scored stainless steel rod (rubbed arteries). The absence of endothelium was checked either by silver staining or by testing the absence of relaxant response to acetylcholine. To assess the participation of NO in the response of renal artery to endothelin-1, concentrationresponse curves for this peptide were obtained after incubation $(20 \mathrm{~min})$ of the renal arteries with the inhibitor of NO synthase (NOS) $N^{\mathrm{G}}$-nitro-L-arginine (L-NOARG, $10^{-4}$ M). To examine the possibility that some arachidonic acid derivative could modulate the arterial response to endothelin1 , we obtained concentration-response curves for endothelin1 after incubation $(20 \mathrm{~min}$ ) of the arterial segments with either indomethacin $\left(10^{-5} \mathrm{M}\right)$, an inhibitor of cyclooxygenase 1 and 2 , or nimesulide $\left(10^{-6} \mathrm{M}\right)$, a selective inhibitor of cyclooxygenase 2 . To verify the endothelial origin of the arachidonic acid derivatives, concentration-response curves for endothelin-1 after incubation with indomethacin $\left(10^{-5} \mathrm{M}\right)$ were obtained in rubbed arteries. To check the participation of specific endothelin $\mathrm{ET}_{\mathrm{A}}$ receptors, concentration-response curves for endothelin-1 were obtained in the presence of selective endothelin $\mathrm{ET}_{\mathrm{A}}$ receptor antagonist cyclo-(D-AspPro-D-Val-Leu-D-Trp) (BQ-123, $\left.10^{-6} \mathrm{M}\right)$. To assess the participation of specific endothelin $\mathrm{ET}_{\mathrm{B}}$ receptors, concentration-response curves for endothelin-1 were obtained, in unrubbed and rubbed arteries, in the presence of selective endothelin $\mathrm{ET}_{\mathrm{B}}$ receptor antagonist 2,6-Dimethylpiperidinecarbonyl- $\gamma$-Methyl-Leu- $\mathrm{N}_{\text {in }}$-(Methoxycarbonyl)-D-Trp-D-Nle (BQ-788, $10^{-6} \mathrm{M}$ ). Finally, to study the dependence of arachidonic acid derivatives on the endothelin $\mathrm{ET}_{\mathrm{A}}$ and $\mathrm{ET}_{\mathrm{B}}$ receptors concentration-response curves for endothelin-1 were obtained in arteries with endothelium in the presence of indomethacin $\left(10^{-5} \mathrm{M}\right)$ plus BQ-123 $\left(10^{-6} \mathrm{M}\right)$ and in rubbed arteries incubated with indomethacin $\left(10^{-5} \mathrm{M}\right)$ plus BQ-788 $\left(10^{-6} \mathrm{M}\right)$.

\subsection{Drugs and solutions}

Alloxan, endothelin-1, indomethacin, nimesulide, BQ-123 and BQ-788 were obtained from Sigma and L-NOARG from Peptide Institute Inc. Alloxan was dissolved in saline solution. Endothelin-1 was dissolved in $0.1 \%$ aqueous acetic acid and diluted in a mixture of phosphate-buffered saline solution $(\mathrm{NaCl}$ $150 \mathrm{mM}+\mathrm{NaH}_{2} \mathrm{PO}_{4} 10 \mathrm{mM}$ ) and $0.05 \%$ bovine serum albumin.
BQ-123, BQ-788 and L-NOARG were dissolved in twicedistilled water; the L-NOARG solution required sonication to dissolve completely. Indomethacin and nimesulide were dissolved in ethanol and diluted in saline solution. The composition of the Ringer-Locke solution was $(\mathrm{mM}): \mathrm{NaCl}$, 120; KCl, 5.4; $\mathrm{CaCl}_{2}, 2.2 ; \mathrm{MgCl}_{2}, 1.0 ; \mathrm{NaHCO}_{3}, 25$; and glucose, 5.6. To prepare the $\mathrm{KCl}$-depolarising solution, $\mathrm{NaCl}$ was replaced by an equimolar amount of $\mathrm{KCl}$ in the normal Ringer-Locke solution.

\subsection{Statistical analysis}

Comparisons of body weight and glycaemia between control and diabetic rabbits were made by using unpaired Student's $t$ test. Endothelin-1 induced contractions are expressed as a percentage of the previous depolarisation induced by $50 \mathrm{mM}$ $\mathrm{KCl}$. For each concentration-response curve the maximum effect $\left(E_{\max }\right)$ and the concentration of endothelin-1 which produced half of $E_{\max }\left(\mathrm{EC}_{50}\right)$ were calculated. Maximum effects are expressed as mean \pm S.E.M. and $\mathrm{EC}_{50}$ as the geometric mean with its confidence limits (95\%) for repeated experiments. Statistical comparisons of $E_{\max }$ and - $\log \mathrm{EC}_{50}\left(\mathrm{pD}_{2}\right)$ values of the concentration-response curves for endothelin-1 obtained with the different treatments in the arteries were achieved by using unpaired Student's $t$-test. A probability value of less than $5 \%$ was considered significant.

\section{Results}

ET-1 $\left(10^{-12}-3 \times 10^{-8} \mathrm{M}\right)$ induced a concentration-dependent contraction of the renal artery from either control or diabetic rabbits (Fig. 1). The $\mathrm{pD}_{2}$ value of the concentrationresponse curve was significantly lower in arteries from diabetic rabbits than in arteries from control rabbits, without significant differences between $E_{\max }$ values (Table 2). In arteries from control rabbits, mechanical removal of the endothelium significantly increased both the $E_{\max }$ and the $\mathrm{pD}_{2}$ values of the concentration-response curves for endothelin-1 (Fig. 2,

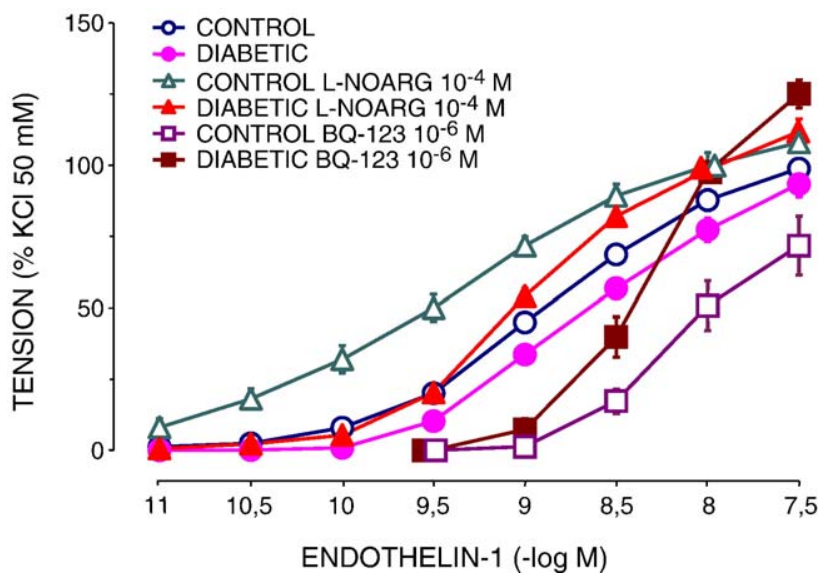

Fig. 1. Concentration-response contractile curves for endothelin-1 in renal arteries isolated from control and diabetic rabbits: control, incubated with LNOARG $\left(10^{-4} \mathrm{M}\right)$ and incubated with BQ-123 $\left(10^{-6} \mathrm{M}\right)$. Values represent means \pm S.E.M. 
Table 2

Maximum effect $\left(E_{\max }\right)$ and $\mathrm{pD}_{2}$ values for concentration-response curves for ET-1 in rabbit renal artery

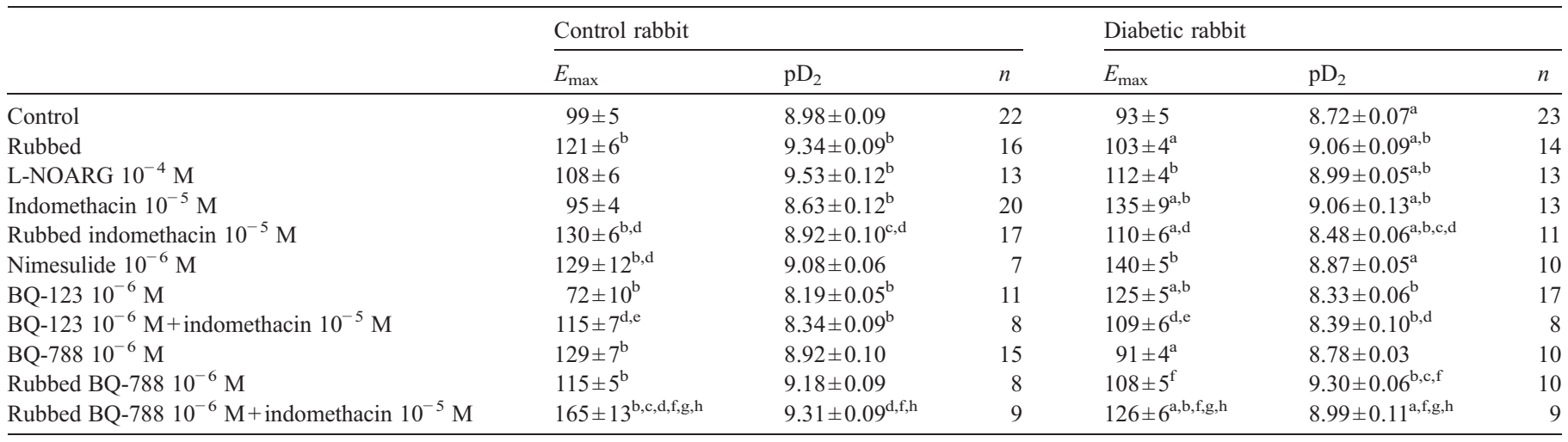

$E_{\max }$ values are expressed as a percentage of a previous depolarisation with $\mathrm{KCl} 50 \mathrm{mmol} / \mathrm{l} . E_{\max }$ and $\mathrm{pD}_{2}$ values are means \pm S.E.M.; $n$ : number of arterial segments. ${ }^{\mathrm{a}}$ Significantly different from corresponding value in control rabbits, $P<0.05 ;{ }^{\mathrm{b}}$ significantly different from corresponding control value, $P<0.05$; ${ }^{\mathrm{c}}$ significantly different from corresponding rubbed value, $P<0.05 ;{ }^{\mathrm{d}}$ significantly different from corresponding indomethacin value, $P<0.05$; ${ }^{\mathrm{e}}$ significantly different from corresponding BQ-123 value, $P<0.05$; ${ }^{\mathrm{f}}$ significantly different from corresponding BQ-788 value, $P<0.05 ;{ }^{\mathrm{g}}$ significantly different from corresponding rubbed $\mathrm{BQ}-$ 788 value, $P<0.05 ;{ }^{\mathrm{h}}$ significantly different from corresponding rubbed indomethacin value, $P<0.05$.

Table 2). In arteries from diabetic rabbits, removal of the endothelium significantly increased the $\mathrm{pD}_{2}$ value, without significant changes in $E_{\max }$ value induced by endothelin-1 (Fig. 3, Table 2). The concentration-response curve for endothelin-1 obtained in rubbed arteries from diabetic rabbits showed significantly lower $E_{\max }$ and $\mathrm{pD}_{2}$ values with respect to the values obtained in rubbed arteries from control rabbits (Table 2).

Incubation with L-NOARG $\left(10^{-4} \mathrm{M}\right)$ significantly enhanced the $\mathrm{pD}_{2}$ value of the concentration-response curve for endothelin-1 in arterial segments from control rabbits, without modifying the $E_{\max }$ value, and enhanced both $E_{\max }$ and $\mathrm{pD}_{2}$ values in arteries from diabetic rabbits (Fig. 1, Table 2). The

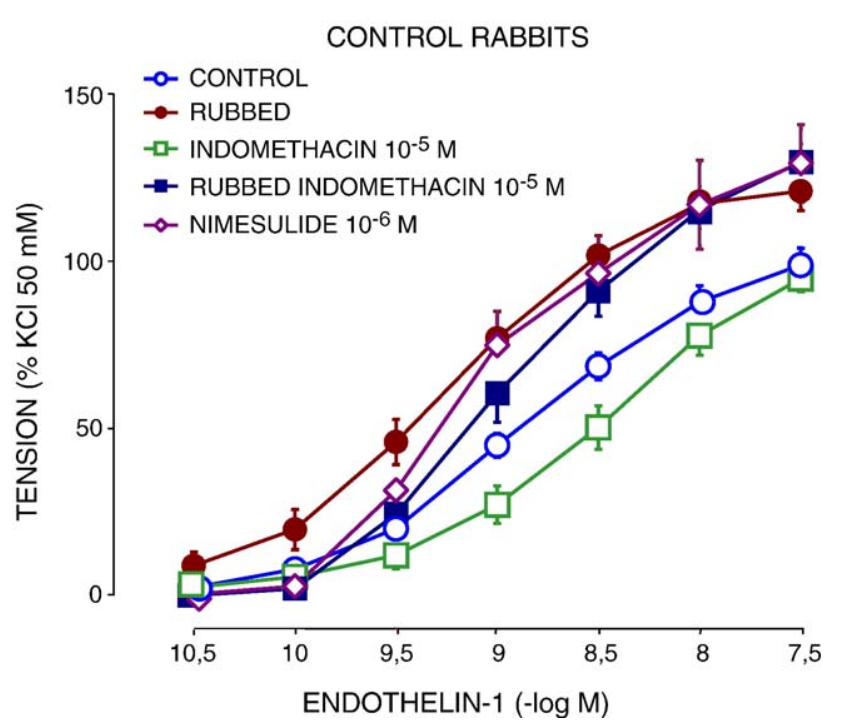

Fig. 2. Concentration-response contractile curves for endothelin-1 in renal arteries isolated from control rabbits: control, without endothelium (rubbed), incubated with indomethacin $\left(10^{-5} \mathrm{M}\right)$, rubbed incubated with indomethacin $\left(10^{-5} \mathrm{M}\right)$, and incubated with nimesulide $\left(10^{-6} \mathrm{M}\right)$. Values represent means \pm S.E.M. concentration-response curve for endothelin-1 obtained in LNOARG pretreated arteries from diabetic rabbits showed a significantly lower $\mathrm{pD}_{2}$ value with respect to its corresponding value in arteries from control rabbits, without significant differences in the $E_{\max }$ values (Table 2).

The incubation of renal arteries from control (Fig. 2) or diabetic (Fig. 3) rabbits with indomethacin $\left(10^{-5} \mathrm{M}\right)$ significantly diminished the $\mathrm{pD}_{2}$ value (displaced to the right) of the concentration-response curve to endothelin-1 in control rabbits (Fig. 2, Table 2) but increased both $E_{\max }$ and $\mathrm{pD}_{2}$ values in diabetic rabbits (Fig. 3, Table 2). The $E_{\max }$ and $\mathrm{pD}_{2}$ values of the concentration-response curve for endothelin-1 obtained in indomethacin-treated arteries from diabetic rabbits were

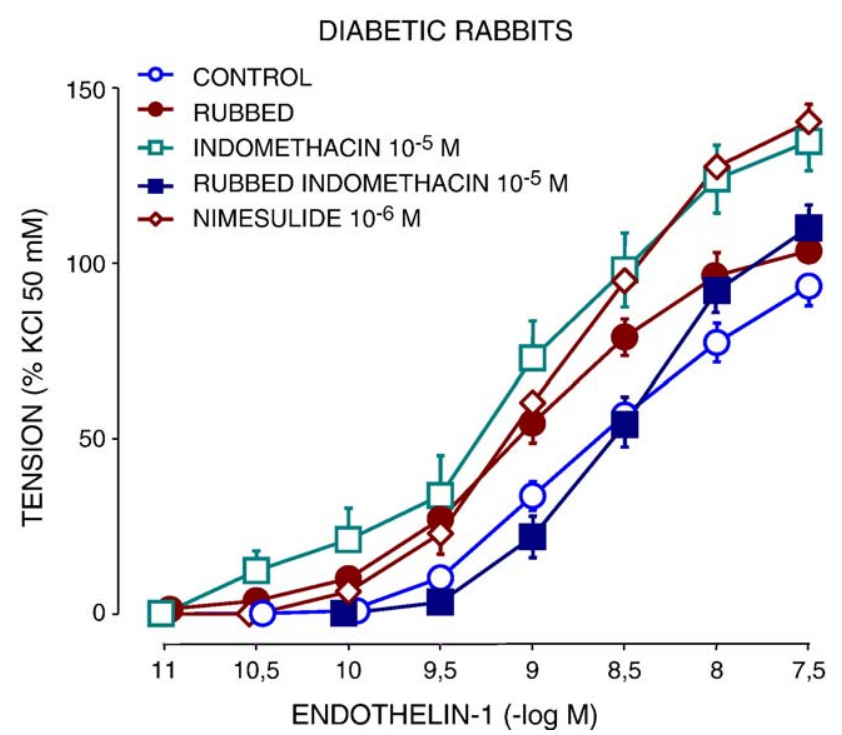

Fig. 3. Concentration-response contractile curves for endothelin-1 in renal arteries isolated from diabetic rabbits: control, without endothelium (rubbed), incubated with indomethacin $\left(10^{-5} \mathrm{M}\right)$, rubbed incubated with indomethacin $\left(10^{-5} \mathrm{M}\right)$, and incubated with nimesulide $\left(10^{-6} \mathrm{M}\right)$. Values represent means \pm S.E.M. 
significantly higher than those obtained in indomethacin-treated arteries from control rabbits (Table 2).

The incubation of rubbed renal arteries either from control (Fig. 2) or diabetic (Fig. 3) rabbits with indomethacin $\left(10^{-5} \mathrm{M}\right)$ significantly diminished the $\mathrm{pD}_{2}$ value of the concentrationresponse curve for endothelin-1 with respect to the corresponding value obtained in rubbed arteries in the absence of indomethacin (Table 2). The $E_{\max }$ and $\mathrm{pD}_{2}$ values of the concentration-response curve for endothelin-1 obtained in indomethacin-treated rubbed arteries from diabetic rabbits were significantly lower than those obtained in indomethacintreated rubbed arteries from control rabbits (Table 2).

The incubation of renal arteries either from control (Fig. 2) or diabetic (Fig. 3) rabbits with nimesulide $\left(10^{-6} \mathrm{M}\right)$ significantly increased the $E_{\max }$ of the concentration-response curve for endothelin-1, without modifying the $\mathrm{pD}_{2}$ value (Table 2). The $\mathrm{pD}_{2}$ value of the concentration-response curve for endothelin-1 obtained in nimesulide-treated arteries from diabetic rabbits was significantly lower than that obtained in nimesulide-treated arteries from control rabbits (Table 2).

The incubation with BQ-123 $\left(10^{-6} \mathrm{M}\right)$ significantly inhibited the contractile response to endothelin-1 of renal arteries from control rabbits (Fig. 1, Table 2) but enhanced it in arteries from diabetic rabbits (Fig. 1, Table 2). The incubation of BQ-123 $\left(10^{-6} \mathrm{M}\right)$-pretreated renal arteries either from control or diabetic rabbits with indomethacin $\left(10^{-5} \mathrm{M}\right)$ significantly increased the $E_{\max }$ value of the concentration-response curve for endothelin-1 in control rabbits (Table 2) but inhibited the $E_{\max }$ value in diabetic rabbits (Table 2) with respect to the corresponding value obtained in BQ-123 $\left(10^{-6} \mathrm{M}\right)$-pretreated arteries in the absence of indomethacin.

The incubation of renal arteries from control rabbits with BQ-788 $\left(10^{-6} \mathrm{M}\right)$ significantly increased the $E_{\max }$ value of the

\section{ejp63344Ip-eps.4}

\section{CONTROL RABBITS}

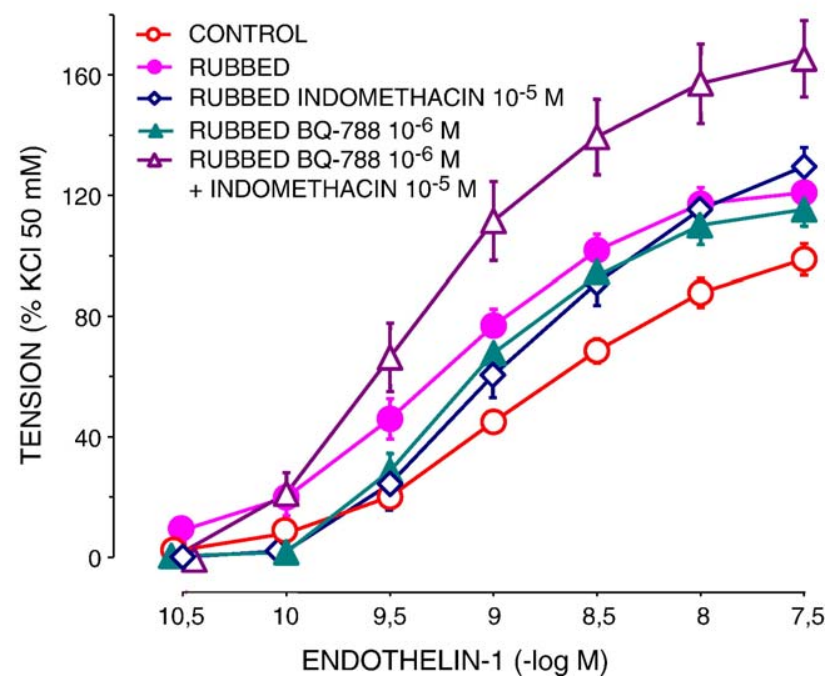

Fig. 4. Concentration-response contractile curves for endothelin-1 in renal arteries isolated from control rabbits: control, without endothelium (rubbed),

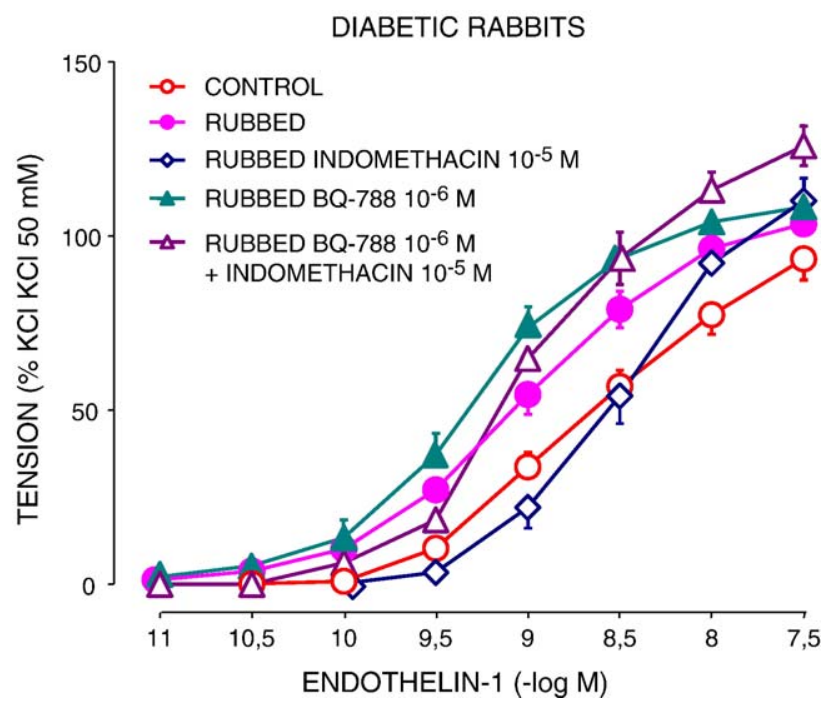

Fig. 5. Concentration-response contractile curves for endothelin-1 in renal arteries isolated from diabetic rabbits: control, without endothelium (rubbed), rubbed incubated indomethacin $\left(10^{-5} \mathrm{M}\right)$, rubbed incubated with BQ-788 $\left.10^{-6} \mathrm{M}\right)$, and rubbed incubated with BQ-788 $\left(10^{-6} \mathrm{M}\right)$ plus indomethacin $\left(10^{-5} \mathrm{M}\right)$. Values represent means \pm S.E.M.

concentration-response curve for endothelin-1, without modifying the $\mathrm{pD}_{2}$ value (Fig. 4, Table 2). In arteries from diabetic rabbits, incubation with $\mathrm{BQ}-788\left(10^{-6} \mathrm{M}\right)$ did not significantly modify the contractile response to endothelin-1 (Fig. 5, Table $2)$. The $E_{\max }$ of the concentration-response curve for endothelin-1 obtained in BQ-788-treated arteries from diabetic rabbits was significantly lower than that obtained in BQ-788treated arteries from control rabbits (Table 2).

The incubation of rubbed renal arteries either from control (Fig. 4) or diabetic (Fig. 5) rabbits with BQ-788 $\left(10^{-6} \mathrm{M}\right) \mathrm{did}$ not modify (control rabbits) or significantly increased the $\mathrm{pD}_{2}$ value (diabetic rabbits) of the concentration-response curve for endothelin-1 with respect to the corresponding value obtained in rubbed arteries in the absence of BQ-788 (Table 2).

The incubation with indomethacin $\left(10^{-5} \mathrm{M}\right)$ of rubbed renal arteries from either control (Fig. 4) or diabetic (Fig. 5) rabbits pretreated with $\mathrm{BQ}-788\left(10^{-6} \mathrm{M}\right)$ significantly enhanced the contractile response to endothelin-1 with respect to the corresponding curve obtained in rubbed arteries incubated only with BQ-788 (Table 2). The $E_{\max }$ and the $\mathrm{pD}_{2}$ values of the concentration-response curve for endothelin-1 obtained in BQ788 plus indomethacin treated rubbed arteries from diabetic rabbits were significantly lower than those obtained in BQ-788 plus indomethacin treated rubbed arteries from control rabbits (Table 2).

\section{Discussion}

Endothelin-1 induced a concentration-dependent contraction of the rabbit renal artery which was slight but significantly less potent in arterial segments from diabetic rabbits, suggesting that diabetes decreases the sensitivity of the isolated rabbit renal artery to endothelin-1. Several studies have shown reduced responsiveness to endothelin-1 in the 
blood vessels of diabetic animals (Hodgson and King, 1992; Chakravarthy et al., 1994). In patients with diabetes type II the vasoconstrictor responses to exogenous endothelin-1 are impaired in the forearm blood flow (Nugent et al., 1996; Cardillo et al., 2002). In contrast, diabetes does not modify the contractile response of rat basilar artery to endothelin-1 (Mayhan, 1998) and increases sensitivity of human cutaneous resistance arteries to endothelin-1 (McIntyre et al., 2001).

Endothelium denudation of arterial rings enhanced the contractile response of renal artery to endothelin-1, both in terms of $E_{\max }$ and $\mathrm{pD}_{2}$ in control rabbits, and only in terms of $\mathrm{pD}_{2}$ (displaced to the left the concentration-response curve for endothelin-1) in diabetic rabbits, thus indicating that the endothelium partially counteracts the endothelin-1-mediated vasoconstriction. The endothelin-1 induced contraction of endothelium-denuded diabetic arteries was significantly lower than that obtained in endothelium-denuded arteries from control rabbits. Therefore, the decreased sensitivity of diabetic renal arteries to endothelin- 1 cannot be attributed to a reduced release of vasodilator endothelial modulators.

We studied the possibility that the modulatory action of the endothelium could be achieved, at least partially, through the release of NO. Incubation of renal arteries from control rabbits with the inhibitor of the constitutive NOS, L-NOARG, significantly enhanced the sensitivity of arterial segments to endothelin-1, without modifying the maximal contraction, thus indicating the participation of $\mathrm{NO}$ in the modulatory action of the endothelium on this response. This seems consistent with in vivo studies which have demonstrated that endothelin-1 stimulates the release of NO in the human forearm circulation (Cardillo et al., 2000). In arteries from diabetic rabbits, L-NOARG significantly enhanced the contraction induced by endothelin-1, both in terms of $E_{\max }$ and $\mathrm{pD}_{2}$. This result suggests that diabetes enhances the modulatory action of endothelial $\mathrm{NO}$ on the response of the renal artery to endothelin-1. Results previously obtained in our laboratory show that experimental diabetes enhances the modulatory activity of endothelial constitutive $\mathrm{NO}$ on the response of either the rabbit renal artery to acetylcholine (Alabadí et al., 2001) or the rabbit carotid artery to 5hydroxytryptamine (Miranda et al., 2000b). In addition, we have also reported that diabetes does not modify the sensitivity of vascular smooth muscle to $\mathrm{NO}$ in the rabbit renal artery (Alabadí et al., 2001). Therefore, our results suggest that diabetes enhances the production of NO from the endothelial cells of the rabbit renal artery.

In the present work, we examined the participation of arachidonic acid metabolites derived via COX in the modulation of the response of the renal artery to endothelin- 1 . In arteries from control rabbits, indomethacin, an inhibitor of both COX-1 and COX-2, significantly decreased the sensitivity of the renal artery to endothelin-1, but nimesulide, a selective inhibitor of COX-2, significantly enhanced the contractions to endothelin-1. Our results suggest that the response of the renal artery to endothelin- 1 is modulated by the release of a vasoconstrictor prostanoid via $\mathrm{COX}-1$, and a vasodilator prostanoid via COX-2, predominating the influence of vaso- constrictor prostanoid on that of vasodilator one. These results are in agreement with those obtained in rats suggesting that cyclooxygenase metabolites from arachidonic acid contribute to endothelin-1 afferent arteriolar vasoconstrictor response (Imig et al., 2000). On the other hand, our results indicate that COX-2 is expressed in the renal artery of control rabbits. COX-2 is expressed in vasculature of normal adult human kidney (Therland et al., 2004). Celecoxib, a COX-2 selective inhibitor, diminishes medullar prostacyclin and thromboxane $\mathrm{A}_{2}$ concentration in the kidney of the rabbit (Miyataka et al., 2002) lowering the ratio prostacyclin/thromboxane $\mathrm{A}_{2}$ (Lomnicka et al., 2003). In addition, celecoxib blocks prostacyclin production of human umbilical vein endothelial cells (Smith et al., 2002). However, our results are in contrast with the absence of effect of nimesulide on vasoconstrictor action of arachidonic acid in the rat kidney suggesting that $\mathrm{COX}-2$ isoform is not expressed (Quilley and Chen, 2003). Probably, these differences could be explained because of species variability.

In arteries from diabetic rabbits either indomethacin or nimesulide significantly enhanced the arterial response to endothelin-1, suggesting that diabetes alters the balance between vasoconstrictor (COX-1) and vasodilator (COX-2) prostanoids in favour of the last ones. This change could contribute to the decreased sensitivity of the renal artery to endothelin-1 in diabetes. Several studies have described a decreased formation of vasoconstrictor prostanoid in rat mesenteric arterial bed in response to methoxamine (Makino and Kamata, 1998), rabbit carotid arteries in response to acetylcholine (Miranda et al., 2000a) or 5-hydroxytryptamine (Miranda et al., 2000b) and rabbit renal arteries in response to 5hydroxytryptamine (Miranda et al., 2002) in diabetes. In contrast, we have reported an increased production of vasoconstrictor prostanoids in the carotid artery from diabetic rabbits in response to endothelin-1 (Lloréns et al., 2004). Moreover, the renal production of thromboxane $\mathrm{A}_{2}$ and prostacyclin is increased in diabetic rats (Okumura et al., 2000). In addition, in rat kidney diabetes induces an increase in vasoconstrictor prostanoids via COX-2 (Quilley and Chen, 2003). These data support the specificity of the changes in modulatory mechanisms of the arterial response to endothelin-1 mentioned above, and show that changes in vascular reactivity induced by diabetes may vary depending on the species, vascular bed and stimuli studied. A recent study reports the existence of sex and regional differences in the alterations induced by diabetes on the reactivity of vascular smooth muscle (Sanz et al., 2003).

In arteries without endothelium from control and diabetic rabbits, indomethacin significantly decreased the sensitivity of the renal artery to endothelin-1 with respect to that obtained in the absence of the inhibitor, thus suggesting that COX-1 vasoconstrictor prostanoid is released from vascular smooth muscle cells, as has been described in rat perfused juxtamedullary nephron (Imig et al., 2000).

The vascular actions of endothelin-1 are primarily mediated by two distinct G-protein-coupled receptor subtypes designated endothelin $\mathrm{ET}_{\mathrm{A}}$ and $\mathrm{ET}_{\mathrm{B}}$ (Hopfner and Gopalakrishnan, 1999). Both endothelin $\mathrm{ET}_{\mathrm{A}}$ and endothelin $\mathrm{ET}_{\mathrm{B}}$ receptors are located 
in smooth muscle cells and mediate vasoconstriction. Endothelin $\mathrm{ET}_{\mathrm{B}}$ receptors are also located in the endothelium and mediate vasodilation through the activation of the release of $\mathrm{NO}$ and prostacyclin. In control rabbits, the antagonist of endothelin $\mathrm{ET}_{\mathrm{A}}$ receptors, $\mathrm{BQ}-123$, significantly inhibited the contractile response of the renal artery to endothelin-1, and the antagonist of $\mathrm{ET}_{\mathrm{B}}$ receptors BQ-788 significantly enhanced the contractile action of endothelin-1. These results are in agreement with those obtained in rabbits (Evans et al., 2000) and rats (Just et al., 2004) showing a net vasoconstrictor influence of endothelin $\mathrm{ET}_{\mathrm{A}}$ receptors and a net vasodilator influence of endothelin $\mathrm{ET}_{\mathrm{B}}$ receptors on renal blood flow.

In diabetic rabbits, BQ-123 significantly enhanced the contraction of the renal artery to endothelin-1 but BQ-788 did not modify it. These results suggest that diabetes induces changes in the role of specific endothelin $\mathrm{ET}_{\mathrm{A}}$ and $\mathrm{ET}_{\mathrm{B}}$ receptors: the activation of endothelin $\mathrm{ET}_{\mathrm{A}}$ receptors has a net vasodilator influence, and the activation of endothelin $\mathrm{ET}_{\mathrm{B}}$ receptors has no influence or, more probably, there is equilibrium between vasoconstrictor and vasodilator influence following their activation. In addition, in the presence of BQ788 the contractile response of renal arteries from diabetic rabbits was lower than that of arteries from control rabbits. This result suggests that the lower sensitivity to endothelin-1 of renal arteries from diabetic animals could be related to a lower contractile activity of endothelin $\mathrm{ET}_{\mathrm{A}}$ receptors. Other studies have also reported a decrease of vasoconstrictor activity of endothelin-1 (Makino and Kamata, 1998; McAuley et al., 2000; Ajayi et al., 2004) in diabetes. However, it has been reported an enhanced activity of endogenous endothelin1 on endothelin $\mathrm{ET}_{\mathrm{A}}$ receptors in the resistance vessels of patients with type II diabetes (Cardillo et al., 2002); nevertheless, the decrease in the contractile action of exogenous endothelin-1 observed in that study suggests that the enhanced activity is more related to an increased level of endogenous endothelin than to an increased sensitivity of the endothelin $\mathrm{ET}_{\mathrm{A}}$ receptor.

In the present study we have examined the relationship between the loss of COX-1 prostanoid vasoconstrictor activity in diabetes and the observed changes in the role of specific endothelin $\mathrm{ET}_{\mathrm{A}}$ and $\mathrm{ET}_{\mathrm{B}}$ receptors. In arteries from control rabbits, in the presence of BQ-123 the incubation with indomethacin enhanced contractile response to endothelin-1, thus indicating the existence of a net vasodilator influence of prostanoids activated by endothelin $\mathrm{ET}_{\mathrm{B}}$ receptors. In contrast, in arteries from diabetic rabbits, in the presence of BQ-123 the incubation with indomethacin inhibited contractile response to endothelin-1, thus indicating the existence in diabetes of a net vasoconstrictor influence of prostanoids activated by endothelin $\mathrm{ET}_{\mathrm{B}}$ receptors. Contractions of guinea-pig gallbladder caused via $\mathrm{ET}_{\mathrm{B}}$ receptors are mediated to a large extent by contractile eicosanoids (Nora et al., 2000).

In rubbed arteries from control rabbits, the incubation with BQ-788 did not significantly modify the contractile action of endothelin-1. This result, together with the enhancement of the contractile response induced by BQ-788 in arteries with endothelium suggests that the vasodilation after activation of endothelin $\mathrm{ET}_{\mathrm{B}}$ receptors is mediated by endothelium, probably through NO and COX-2 vasodilator prostanoids. Similar results have been reported showing that the activation of endothelial endothelin $\mathrm{ET}_{\mathrm{B}}$ receptors produces vasodilation mediated by nitric oxide and eicosanoids (Cardillo et al., 2000; D'OrleansJuste et al., 2002). In rubbed arteries from diabetic rabbits, the incubation with BQ-788 increased the contractile potency of endothelin-1, thus showing the existence in diabetes of a vasodilatory action mediated by endothelin $\mathrm{ET}_{\mathrm{B}}$ receptors (probably through $\mathrm{NO}$ and COX-2 vasodilator prostanoids released from vascular smooth muscle cells). Therefore, our results suggest that, in diabetes, the activation of endothelin $\mathrm{ET}_{\mathrm{B}}$ receptors induces the release of $\mathrm{COX}-1$ vasoconstrictor prostanoids which counteracts the release of $\mathrm{NO}$ and COX-2 vasodilator prostanoids.

Finally, both in control and diabetic rabbits, the incubation with indomethacin of rubbed arteries pretreated with BQ-788 induced an enhancement of the contractile action of endothelin-1, thus suggesting that activation of $\mathrm{ET}_{\mathrm{A}}$ receptors induces the release from the smooth muscle cells of prostanoids with a net vasodilator activity. Other studies have reported the release of vasodilator prostanoids after activation of endothelin $\mathrm{ET}_{\mathrm{A}}$ receptors (Wright and Malik, 1995; Nora et al., 2000). The contractile action of endothelin1 in rubbed arteries incubated with BQ-788 plus indomethacin in diabetic rabbits was lower than the corresponding action in arteries from control rabbits; because of the fact that in the absence of indomethacin there were not significant differences, these results suggest that diabetes diminishes the vasodilator activity of the prostanoids released from smooth muscle cells in response to activation of endothelin $\mathrm{ET}_{\mathrm{A}}$ receptors. This decreased vasodilator activity would not explain the loss of vasoconstrictor influence of the activation of endothelin $\mathrm{ET}_{\mathrm{A}}$ receptors observed in diabetes, which could probably be explained by the impairment of COX-1 prostanoid vasoconstrictor release.

In summary, diabetes induces complexes changes in the regulatory mechanisms that regulate the contractile response of the rabbit renal artery to endothelin-1: (1) enhancement of endothelial NO; (2) altered balance between vasoconstrictor $(\mathrm{COX}-1)$ and vasodilator (COX-2) prostanoids in favour of the last ones; and (3) decreased ratio between vasoconstrictor and vasodilator prostanoids released after activation of endothelin $\mathrm{ET}_{\mathrm{A}}$ receptors predominating on the increased ratio after activation of endothelin $\mathrm{ET}_{\mathrm{B}}$ receptors. The sum of these changes results in a decrease in the sensitivity of the renal artery to this peptide. The possible vascular implications for the use of COX-inhibitors and endothelin-related drugs should be considered in diabetic patients.

\section{Acknowledgements}

This study was supported in part by grants from University of Valencia (ref. UV01-01) and Generalitat Valenciana (ref. GRUPO05/014). The authors are grateful to Salvador Banacloche for his technical assistance. 


\section{References}

Ajayi, A.A., Ogungbade, G.O., Hercule, H.C., Oyekan, A.O., Mutembei, L., 2004. Alteration in endothelin receptor sub-type responsiveness and in the endothelin-TXA 2 mimetic U46619 interaction, in type-2 hypertensive diabetic Zucker rats. Diabetes Res. Clin. Pract. 63, 155-169.

Alabadí, J.A., Miranda, F.J., Lloréns, S., Ruiz de Apodaca, R.F., Centeno, J.M., Alborch, E., 2001. Diabetes potentiates acetylcholine-induced relaxation in rabbit renal arteries. Eur. J. Pharmacol. 415, 225-232.

Alabadí, J.A., Miranda, F.J., Lloréns, S., Centeno, J.M., Marrachelli, V.G., Alborch, E., 2004. Mechanisms underlying diabetes enhancement of endothelin-1-induced contraction in rabbit basilar artery. Eur. J. Pharmacol. 486, 289-296.

Campean, V., Theiling, F., Paliege, A., Breyer, M., Bachmann, S., 2003. Key enzymes for renal prostaglandin synthesis: site-specific expression in rodent kidney (rat, mouse). Am. J. Physiol., Renal Physiol. 285, F19-F32.

Cardillo, C., Kilcoyne, C.M., Cannon, R.O., Iii, Panza, J.A., 2000. Interactions between nitric oxide and endothelin in the regulation of vascular tone of human resistance vessels in vivo. Hypertension 35, 1237-1241.

Cardillo, C., Campia, U., Bryant, M.B., Panza, J.A., 2002. Increased activity of endogenous endothelin in patients with type II diabetes mellitus. Circulation 106, 1783-1787.

Chakravarthy, U., McGinty, A., McKillop, J., Anderson, P., Archer, D.B., Trimble, E.R., 1994. Altered endothelin-1 induced contraction and second messenger generation in bovine retinal microvascular pericytes cultured in high glucose medium. Diabetologia 37, 36-42.

De Vriese, A.S., Verbeuren, T.J., Van De Voorde, J., Lameire, N.H., Vanhoutte, P.M., 2000. Endothelial dysfunction in diabetes. Br. J. Pharmacol. 130, 963-974.

D’Orleans-Juste, P., Labonte, J., Bkaily, G., Choufani, S., Plante, M., Honore, J. C., 2002. Function of the endothelin B receptor in cardiovascular physiology and pathophysiology. Pharmacol. Ther. 95, 221-238.

Evans, R.G., Madden, A.C., Cotterill, E., 2000. ET-receptor subtypes: roles in regional renal vascular actions of exogenous and endogenous endothelins in anesthetized rabbits. J. Cardiovasc. Pharmacol. 35, 677-685.

Haberberger, R., Schemann, M., Sann, H., Kummer, W., 1997. Innervation pattern of guinea pig pulmonary vasculature depends on vascular diameter J. Appl. Physiol. 82, 426-434.

Habib, A., Creminon, C., Frobert, Y., Grassi, J., Pradelles, P., Maclouf, J., 1993. Demonstration of an inducible cyclooxygenase in human endothelial cells using antibodies raised against the carboxyl-terminal region of the cyclooxygenase-2. J. Biol. Chem. 268, 23448-23454.

Haller, H., 1997. Endothelial function. General considerations. Drugs 53, 1-10.

Hodgson, W.C., King, R.G., 1992. Effects of glucose, insulin or aldose reductase inhibition on responses to endothelin-1 of aortic rings from streptozotocin-induced diabetic rats. Br. J. Pharmacol. 106, 644-649.

Hopfner, R.L., Gopalakrishnan, V., 1999. Endothelin: emerging role in diabetic vascular complications. Diabetologia 42, 1383-1394.

Huidobro-Toro, J.P., Donoso, M.V., 2005. Sympathetic co-transmission: the coordinated action of ATP and noradrenaline and their modulation by neuropeptide $\mathrm{Y}$ in human vascular neuroeffector junctions. Eur. J. Pharmacol. 500, 27-35.

Imig, J.D., Pham, B.T., LeBlanc, E.A., Reddy, K.M., Falck, J.R., Inscho, E.W., 2000. Cytochrome P450 and cyclooxygenase metabolites contribute to the endothelin-1 afferent arteriolar vasoconstrictor and calcium responses. Hypertension 35, 307-312.

Jurzik, L., Froh, M., Straub, R.H., Scholmerich, J., Wiest, R., 2005. Upregulation of nNOS and associated increase in nitrergic vasodilation in superior mesenteric arteries in pre-hepatic portal hypertension. J. Hepatol. $43,258-265$.

Just, A., Olson, A.J., Arendshorst, W.J., 2004. Dual constrictor and dilator actions of $\mathrm{ET}_{\mathrm{B}}$ receptors in the rat renal microcirculation: interactions with ET $_{\mathrm{A}}$ receptors. Am. J. Physiol., Renal Physiol. 286, F660-F668.

Lam, H.C., Lee, J.K., Chiang, H.T., Koh, S.J., Han, T.M., Lu, C.C., Yang, C.Y., Hao, L.J., 1995. Does endothelin play a role in the pathogenesis of early diabetic nephropathy? J. Cardiovasc. Pharmacol. 26 (Suppl.3), S479-S481.
Lomnicka, M., Karouni, K., Sue, M., Wessel, L.A., Bing, R.J., 2003. Effects of nonsteroidal anti-inflammatory drugs on prostacyclin and thromboxane in the kidney. Pharmacology 68, 147-153.

Lloréns, S., Miranda, F.J., Alabadí, J.A., Marrachelli, V.G., Alborch, E., 2004. Different role of endothelin $\mathrm{ET}_{\mathrm{A}}$ and $\mathrm{ET}_{\mathrm{B}}$ receptors and endothelial modulators in diabetes-induced hyperreactivity of the rabbit carotid artery to endothelin-1. Eur. J. Pharmacol. 486, 43-51.

Makino, A., Kamata, K., 1998. Possible modulation by endothelin-1, nitric oxide, prostaglandin $\mathrm{I}_{2}$ and thromboxane $\mathrm{A}_{2}$ of vasoconstriction induced by an alpha-agonist in mesenteric arterial bed from diabetic rats. Diabetologia $41,1410-1418$.

Mayhan, W.G., 1998. Constrictor responses of the rat basilar artery during diabetes mellitus. Brain Res. 783, 326-331.

McAuley, D.F., Nugent, A.G., McGurk, C., Maguire, S., Hayes, J.R., Johnston, G.D., 2000. Vasoconstriction to endogenous endothelin-1 is impaired in patients with type II diabetes mellitus. Clin. Sci. (Lond.) 99, 175-179.

McIntyre, C.A., Hadoke, P.W., Williams, B.C., Lindsay, R.M., Elliott, A.I., McKnight, J.A., 2001. Selective enhancement of sensitivity to endothelin-1 despite normal endothelium-dependent relaxation in subcutaneous resistance arteries isolated from patients with Type I diabetes. Clin. Sci. (Lond.) $100,311-318$.

Miranda, F.J., Alabadí, J.A., Llorens, S., Ruiz De Apodaca, R.F., Centeno, J.M., Alborch, E., 2000a. Influence of experimental diabetes on regulatory mechanisms of vascular response of rabbit carotid artery to acetylcholine. Life Sci. 66, 2071-2080.

Miranda, F.J., Alabadí, J.A., Lloréns, S., Ruiz De Apodaca, R.F., Centeno, J.M., Alborch, E., 2000b. Diabetes-induced changes in endothelial mechanisms implicated in rabbit carotid arterial response to 5-hydroxytryptamine. Eur. J. Pharmacol. 401, 397-402.

Miranda, F.J., Alabadí, J.A., Lloréns, S., Ruiz De Apodaca, R.F., Centeno, J.M., Alborch, E., 2002. Experimental diabetes induces hyperreactivity of rabbit renal artery to 5-hydroxytryptamine. Eur. J. Pharmacol. 439, 121-127.

Miyataka, M., Rich, K.A., Ingram, M., Yamamoto, T., Bing, R.J., 2002. Nitric oxide, anti-inflammatory drugs on renal prostaglandins and cyclooxygenase-2. Hypertension 39, 785-789.

Morrish, N.J., Wang, S.L., Stevens, L.K., Fuller, J.H., Keen, H., 2001. Mortality and causes of death in the WHO multinational study of vascular disease in diabetes. Diabetologia 44 (Suppl 2), S14-S21.

Nora, H.C., Cardozo, A.M., D'Orleans-Juste, P., Rae, G.A., 2000. Influences of indomethacin on contractions induced by endothelins in guinea pig isolated gallbladder. J. Cardiovasc. Pharmacol. 36 (Suppl. 1), S267-S269.

Nugent, A.G., McGurk, C., Hayes, J.R., Johnston, G.D., 1996. Impaired vasoconstriction to endothelin 1 in patients with NIDDM. Diabetes 45, 105-107.

Okumura, M., Imanishi, M., Yamashita, T., Yamamura, Y., Kim, S., Iwao, H., Tanaka, S., Fujii, S., 2000. Renal production of thromboxane and prostaglandins in a rat model of type 2 diabetes. Life Sci. 66, 371-377.

Oyekan, A.O., McGiff, J.C., 1998. Cytochrome P-450-derived eicosanoids participate in the renal functional effects of ET-1 in the anesthetized rat. Am. J. Physiol. 274, R52-R61.

Quilley, J., Chen, Y.J., 2003. Role of COX-2 in the enhanced vasoconstrictor effect of arachidonic acid in the diabetic rat kidney. Hypertension 42, 837-843.

Rimarachin, J.A., Jacobson, J.A., Szabo, P., Maclouf, J., Creminon, C., Weksler, B.B., 1994. Regulation of cyclooxygenase-2 expression in aortic smooth muscle cells. Arterioscler. Thromb. 14, 1021-1031.

Sanz, E., Fernández, N., Monge, L., Martínez, M.A., Climent, B., Diéguez, G., García-Villalón, A.L., 2003. Effects of diabetes on the vascular response to nitric oxide and constrictor prostanoids: gender and regional differences. Life Sci. 72, 1537-1547.

Smith, L.H., Boutaud, O., Breyer, M., Morrow, J.D., Oates, J.A., Vaughan, D.E., 2002. Cyclooxygenase-2-dependent prostacyclin formation is regulated by low density lipoprotein cholesterol in vitro. Arterioscler. Thromb. Vasc. Biol. 22, 983-988.

Sorokin, A., Kohan, D.E., 2003. Physiology and pathology of endothelin-1 in renal mesangium. Am. J. Physiol., Renal Physiol. 285, F579-F589.

Therland, K.L., Stubbe, J., Thiesson, H.C., Ottosen, P.D., Walter, S., Sorensen, G.L., Skott, O., Jensen, B.L., 2004. Cycloxygenase-2 is expressed in 
vasculature of normal and ischemic adult human kidney and is colocalized with vascular prostaglandin $E_{2}$ EP4 receptors. J. Am. Soc. Nephrol. 15, $1189-1198$.

Wright, H.M., Malik, K.U., 1995. Prostacyclin synthesis elicited by endothelin1 in rat aorta is mediated by an $\mathrm{ET}_{\mathrm{A}}$ receptor via influx of calcium and is independent of protein kinase C. Hypertension 26, 1035-1040.
Yanagisawa, M., Kurihara, H., Kimura, S., Tomobe, Y., Kobayashi, M., Mitsui, Y., Yazaki, Y., Goto, K., Masaki, T., 1998. A novel potent vasoconstrictor peptide produced by vascular endothelial cells. Nature 332, 411-415. 